\title{
Winter speed-up of quiescent surge-type glaciers in Yukon, Canada
}

\author{
T. Abe and M. Furuya \\ Department of Natural History Sciences, Graduate School of Science, Hokkaido University, Sapporo, Japan
}

Correspondence to: T. Abe (abetaka@ frontier.hokudai.ac.jp)

Received: 4 April 2014 - Published in The Cryosphere Discuss.: 21 May 2014

Revised: 11 May 2015 - Accepted: 11 May 2015 - Published: 5 June 2015

\begin{abstract}
Glacier surges often initiate in winter, but the mechanism remains unclear in contrast to the well-known summer speed-up at normal glaciers. To better understand the mechanism, we used radar images to examine spatialtemporal changes in the ice velocity of surge-type glaciers near the border of Alaska and the Yukon, focusing on their quiescent phase. We found significant accelerations in the upstream region from autumn to winter, regardless of surging episodes. Moreover, the winter speed-up propagated from upstream to downstream. Given the absence of surface meltwater input in winter, we suggest the presence of water storage near the base that does not directly connect to the surface, yet can promote basal sliding through increased water pressure. Our findings have implications for the modelling of glacial hydrology in winter, which may help us better understand glacier dynamics.
\end{abstract}

\section{Introduction}

Ice flow on mountain glaciers and ice sheets typically shows greatest acceleration from spring to early summer, followed by deceleration in midsummer to autumn (e.g. Iken and Bindschadler, 1986; MacGregor et al., 2005; Sundal et al., 2011). These speed changes are attributed to subglacial slip associated with water pressure changes, and these changes arise from seasonal variability of meltwater input and the evolution of the subglacial hydraulic system (Schoof, 2010; Bartholomaus et al., 2011; Hewitt, 2013; Werder et al., 2013). From spring to early summer, meltwater from the surface reaches the bed, and develops an "inefficient" drainage system, in which water flow channels are not well developed, producing a high basal water pressure. The high water pressure increases basal slip, which increases the surface velocity. As the amount of meltwater increases, the basal drainage system becomes "efficient" due to the enlarging channels (Röthlisberger, 1972). The larger channels allow a higher meltwater flux with lower water pressure, causing a gradual decrease in surface velocity. In late summer to autumn, when meltwater input terminates, surface velocity has its yearly minimum. Meltwater input and subsequent evolution of the drainage system evidently influence surface ice speeds from spring to autumn.

Several studies have reported that surface ice speeds in winter were in between the early summer maximum and early autumn minimum (e.g. Iken and Truffer, 1997; Sundal et al., 2011; Burgess et al., 2013a). Some recent studies also indicate that the amount of surface meltwater in summer can influence the velocity evolution in winter, in a way that reduces the annual ice flow (Burgess et al., 2013b; Sole et al., 2013). However, there have been relatively few comprehensive velocity measurements throughout wintertime, particularly in the middle-to-upstream regions of mountain glaciers. Although the first velocity map over entire Alaska and the Yukon glaciers was shown by Burgess et al. (2013a), they did not show the spatial and temporal changes in ice velocity.

Nevertheless, it is well known that glacier surges often initiate in winter, exhibiting speed-up which was several orders of magnitude and resulting in $\mathrm{km}$-scale terminus advance (Meier and Post, 1969; Raymond, 1987). In order to interpret both the wintertime surge initiation and the intermediate values of winter speed, cavity closure and subsequent water pressure increase are often envisaged, starting with the surge mechanism proposed for the 1982-1983 surge at the Variegated Glacier by Kamb et al. (1985). Even in winter, there may be some remnants of summer meltwater that can increase the water pressure (Iken and Truffer, 1997). However, in the absence of meltwater input, the subglacial cavities are increasingly disconnected in winter, resulting in a "stickier" bed even if the water pressure in each cavity becomes high lo- 
cally (Bartholomaus et al., 2011). Hence, it remains an open question as to why and how the water pressure increase and subsequent speed-up can be maintained without further input of meltwater from the surface. Do the surface velocities monotonously increase from later summer to the next spring? Such an increase is often assumed, but the process would require some extra sources of water to maintain the higher water pressure. The wintertime dynamics of sub- and englacial water is thus yet to be fully understood. Reaching an understanding requires new continuous measurements.

The St. Elias Mountains, near the border of Alaska, USA, and the Yukon, Canada (Fig. 1), contain numerous surge-type glaciers (Meier and Post, 1969). But only a few of these have been studied and reported on in literature (e.g. Clarke et al., 1984; Truffer et al., 2000; Flowers et al., 2011; Burgess et al., 2012). Our understanding of surge-type glacier dynamics is still limited (Raymond, 1987; Harrison and Post, 2003; Cuffey and Paterson, 2010), because few detailed observations have been performed over a complete surge-cycle.

Recent advances in remote sensing techniques allow us to survey the ice velocity distribution over the entire St. Elias Mountains. Here we present the spatial and temporal changes in ice velocity for the surge-type glaciers, focusing particularly on the seasonal cycle during the quiescent phases to better understand the wintertime behaviour. The three glaciers (Chitina, Anderson, and Walsh) are examined in detail to reveal the speed changes in the upper and the lower regions. On the other hand, the active surging occurred at four glaciers (Lowell, Tweedsmuir, Ottawa, and Logan) in the analysis period, and the details of these glaciers are described in the Supplement.

Understanding the dynamics of surge-type glaciers is also important for better simulating future ice dynamics in the St. Elias Mountains. Significant contributions of the Alaskan glaciers' retreat to a possible rise in sea level due to global warming have been estimated (Radić and Hock, 2011), but projections of glacier mass balance assume non-surge type glaciers whose dynamics is only affected by long-term climate changes. Although the dynamics of surge-type glaciers itself is not directly related to climate change, there have been several pieces of evidence for the impact of climate change on surge cycle (e.g. Harrison and Post, 2003; Frappé and Clarke, 2007).

\section{Data sets and analysis method}

\subsection{ALOS/PALSAR data}

We processed phased array-type L-band (wavelength $23.6 \mathrm{~cm}$ ) synthetic aperture radar (PALSAR) images from the Advanced Land Observation Satellite (ALOS) operated by the Japan Aerospace Exploration Agency (JAXA). Scenes were acquired along multiple paths (Fig. 1, Table 1). ALOS was launched on January 2006, and its operation was ter-

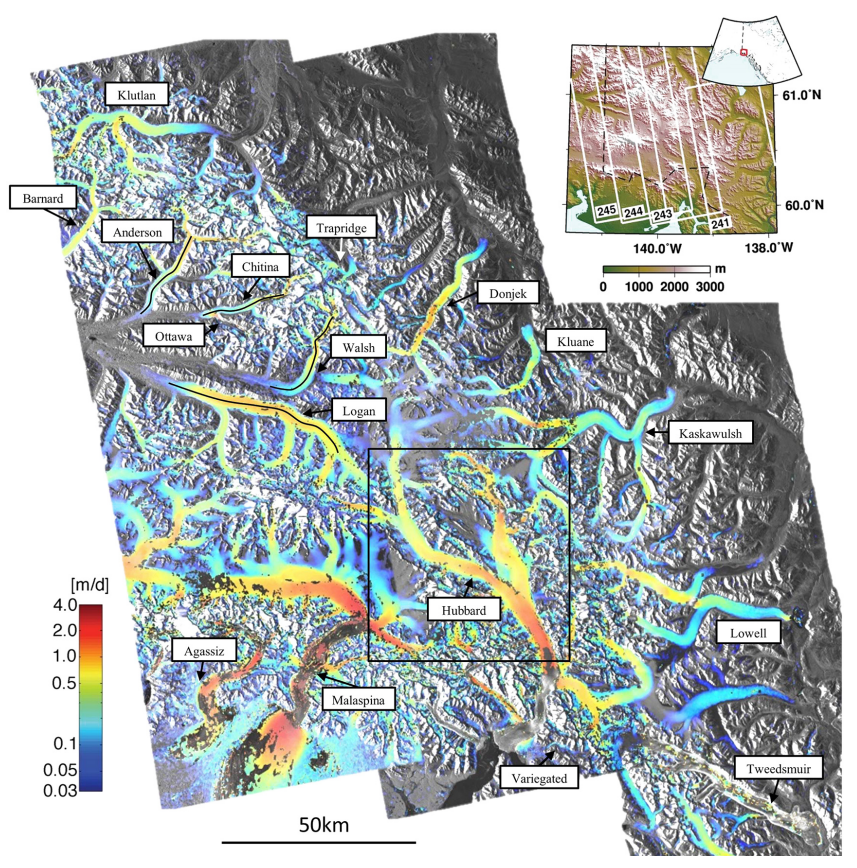

Figure 1. Composite ice-speed map of the study area. The individual maps for the study area were derived by intensity tracking between two PALSAR images. The left, middle and right velocity maps are derived from images pairs from 10 February 2010 and 28 March 2010 of Path 245, 30 December 2006 and 14 February 2007 of Path 243, 14 January 2008 and 29 February 2008 of Path 241, respectively. The square region around Hubbard Glacier is shown in Fig. 4. Black lines in some glaciers show the flow line. The upper right panel indicates the location and topography of the study area as well as the satellite's imaging areas.

minated on May 2011. Thus, the data sets for the study area were acquired only for the period of December 2006 to March 2011. The details of the data sets are listed in Table 1. Only FBS (fine-beam single-polarization mode) and FBD (fine-beam dual-polarization mode) data are used in this study because their higher spatial resolutions allowed us to reliably measure the flow velocities. We use Gamma software to process level 1.0 data to generate single-look complex images (Wegmüller and Werner, 1997) and run pixeloffset tracking analyses. See Table 1 for more detail of the data sets.

\subsection{Pixel-offset tracking}

The pixel-offset tracking (or feature or speckle tracking) algorithms used in this study are based on maximizing the cross-correlation of intensity image patches. The method closely follows that used by Strozzi et al. (2002) and Yasuda and Furuya (2013). We used a search patch of $64 \times 192$ pixels (range $\times$ azimuth) with a sampling interval of $4 \times 12$ pixels for most glaciers. But, for the Hubbard Glacier, we used a search patch of $128 \times 384$ pixels, due its large size. We set 4.0 as the threshold of the signal-to-noise ratio, and patches 
Table 1. Data list of the ALOS/PALSAR.

\begin{tabular}{|c|c|c|c|c|c|c|}
\hline Sensor/Path & Frame & Master & Slave & Mode & $\operatorname{Bperp}^{*}(\mathrm{~m})$ & Span (day) \\
\hline \multirow[t]{8}{*}{ PALSAR/241 } & \multirow[t]{8}{*}{$1190-1210$} & 20070829 & 20071014 & FBD-FBD & 597 & 46 \\
\hline & & 20080114 & 20080229 & FBS-FBS & 796 & 46 \\
\hline & & 20090116 & 20090303 & FBS-FBS & 529 & 46 \\
\hline & & 20100119 & 20100306 & FBS-FBS & 756 & 46 \\
\hline & & 20100306 & 20100421 & FBS-FBS & 353 & 46 \\
\hline & & 20100421 & 20100606 & FBS-FBD & 104 & 46 \\
\hline & & 20100606 & 20100722 & FBD-FBD & 122 & 46 \\
\hline & & 20100722 & 20100906 & FBD-FBD & 332 & 46 \\
\hline \multirow[t]{10}{*}{ PALSAR/243 } & \multirow[t]{10}{*}{$1200-1220$} & 20061230 & 20070214 & FBS-FBS & 1342 & 46 \\
\hline & & 20070817 & 20071002 & FBD-FBD & 425 & 46 \\
\hline & & 20071002 & 20080102 & FBD-FBS & 627 & 92 \\
\hline & & 20080102 & 20080217 & FBS-FBS & 1041 & 46 \\
\hline & & 20080819 & 20090104 & FBD-FBS & 1779 & 138 \\
\hline & & 20090104 & 20090219 & FBS-FBS & 652 & 46 \\
\hline & & 20090822 & 20091007 & FBD-FBD & 566 & 46 \\
\hline & & 20091007 & 20100107 & FBD-FBS & 726 & 92 \\
\hline & & 20100107 & 20100222 & FBS-FBS & 794 & 46 \\
\hline & & 20100825 & 20101010 & FBD-FBD & 505 & 46 \\
\hline \multirow[t]{11}{*}{ PALSAR/244 } & \multirow[t]{11}{*}{$1200-1220$} & 20070116 & 20070303 & FBS-FBS & 1554 & 46 \\
\hline & & 20070903 & 20071019 & FBD-FBD & 474 & 46 \\
\hline & & 20071019 & 20080119 & FBD-FBS & 799 & 92 \\
\hline & & 20080905 & 20081021 & FBD-FBD & 672 & 46 \\
\hline & & 20081021 & 20090121 & FBD-FBS & 874 & 92 \\
\hline & & 20090908 & 20091024 & FBD-FBD & 419 & 46 \\
\hline & & 20091024 & 20100124 & FBD-FBS & 960 & 92 \\
\hline & & 20100124 & 20100311 & FBS-FBS & 722 & 46 \\
\hline & & 20100911 & 20101027 & FBD-FBD & 504 & 46 \\
\hline & & 20101027 & 20110127 & FBD-FBS & 997 & 92 \\
\hline & & 20110127 & 20110314 & FBS-FBS & 840 & 46 \\
\hline \multirow[t]{15}{*}{ PALSAR/245 } & \multirow[t]{15}{*}{$1200-1220$} & 20070920 & 20071105 & FBD-FBS & 655 & 46 \\
\hline & & 20071105 & 20071221 & FBS-FBS & 86 & 46 \\
\hline & & 20071221 & 20080205 & FBS-FBS & 884 & 46 \\
\hline & & 20080807 & 20080922 & FBD-FBD & 1027 & 46 \\
\hline & & 20080922 & 20081223 & FBD-FBS & 596 & 92 \\
\hline & & 20090810 & 20090925 & FBD-FBD & 671 & 46 \\
\hline & & 20090925 & 20091226 & FBD-FBS & 776 & 92 \\
\hline & & 20091226 & 20100210 & FBS-FBS & 690 & 46 \\
\hline & & 20100210 & 20100328 & FBS-FBS & 532 & 46 \\
\hline & & 20100328 & 20100513 & FBS-FBD & 169 & 46 \\
\hline & & 20100513 & 20100628 & FBD-FBD & 122 & 46 \\
\hline & & 20100628 & 20100813 & FBD-FBD & 486 & 46 \\
\hline & & 20100813 & 20100928 & FBD-FBD & 470 & 46 \\
\hline & & 20100928 & 20101229 & FBD-FBS & 614 & 92 \\
\hline & & 20101229 & 20110213 & FBS-FBS & 790 & 46 \\
\hline
\end{tabular}

* Bperp stands for the orbit separation distance perpendicular to the radar line of sight.

below this level were treated as missing data. The FBD data are oversampled in the range direction (i.e. satellite to ground direction) so that the range dimension is the same as that of the FBS data.

In the pixel-offset tracking, we corrected for a stereoscopic effect known as an artifact offset over rugged terrain (Strozzi et al., 2002). This is caused by the separation between satellite orbital paths, and the effect of foreshortening which also generates the offsets. We reduced the artifact by applying an elevation-dependent correction, incorporating the Advanced Spaceborne Thermal Emission and Reflection Radiometer (ASTER) global digital elevation model (GDEM) version 2 
data with a $30 \mathrm{~m}$ resolution. We applied the same method described by Kobayashi et al. (2009) and confirmed that few topography-correlated artifact offsets remained.

Using both range and azimuth offset data, we derived the surface velocity data (Fig. 1) by assuming no vertical displacements. The studied glaciers are gently sloped at approximately $1-2^{\circ}$, and thus, the vertical component is much smaller than the horizontal component. In addition, we derived the velocity map using image pairs that were temporally separated by, at most, 138 days. The glaciers' surface elevation change during this period should be negligibly small in comparison to the horizontal movement of the glaciers. To examine the spatial and temporal changes, we first set a flow line at each glacier, and then averaged the velocity pixel data over the $\sim 350 \times 350 \mathrm{~m}^{2}$ area with its centre at the flow line. We estimated the measurement error to be $0.1 \mathrm{~m} \mathrm{~d}^{-1}$ below the standard deviation at each area.

The uncertainties of offset tracking have been estimated to be $\sim 0.3-0.4 \mathrm{~m}$ in the rugged terrain, using two images with ALOS/PALSAR's 46-day interval at non-deforming area (Kobayashi et al., 2009). Assuming linear temporal evolution, the errors in the velocity estimate are inferred to be below $0.1 \mathrm{~m} \mathrm{~d}^{-1}$.

\section{Observation results}

Here we focus on winter speed-up signals at surge-type glaciers that were in their quiescent phase during the analysis period. The Chitina, Anderson, and Walsh Glaciers are the major surge-type glaciers of the Chitina River valley system (Clarke and Holdsworth, 2002), and could be examined with the highest temporal resolution because of the overlap of multiple satellite tracks. The names of 17 major glaciers in the region are shown in Fig. 1. The active surging occurred at four glaciers (Lowell, Tweedsmuir, Ottawa, and Logan), and the details of these glaciers are described in the Supplement.

Figure 2a, c, and e show the spatial-temporal evolution of ice velocity at the three glaciers (Anderson, Chitina and Walsh) along their flow lines shown in Fig. 1. At the $20 \mathrm{~km}$ point on Anderson Glacier (Fig. 2a), the winter speed is more than double the autumn speed. At Chitina Glacier (Fig. 2c), the winter velocities at the $20 \mathrm{~km}$ point exceed $0.5 \mathrm{~m} \mathrm{~d}^{-1}$, which is significantly greater than the autumn velocities of $\sim 0.3 \mathrm{~m} \mathrm{~d}^{-1}$ regardless of the surge signal at Ottawa glacier in 2010 (Black circle in Fig. 2c). At the $20 \mathrm{~km}$ point on Walsh Glacier (Fig. 2e), the winter speed is more than $50 \%$ greater than the autumn speed.

Figure $2 b, d$, and $f$ are time-series plots averaged over the downstream (blue) and upstream (red) section in Fig. 2a, c, and e, respectively. We can recognize the distinct seasonal trends in the upstream and downstream regions. Although the downstream speeds (blue) in early summer are faster than those in winter, the upstream speeds (red) in winter are comparable to, and sometimes faster than those in early sum-
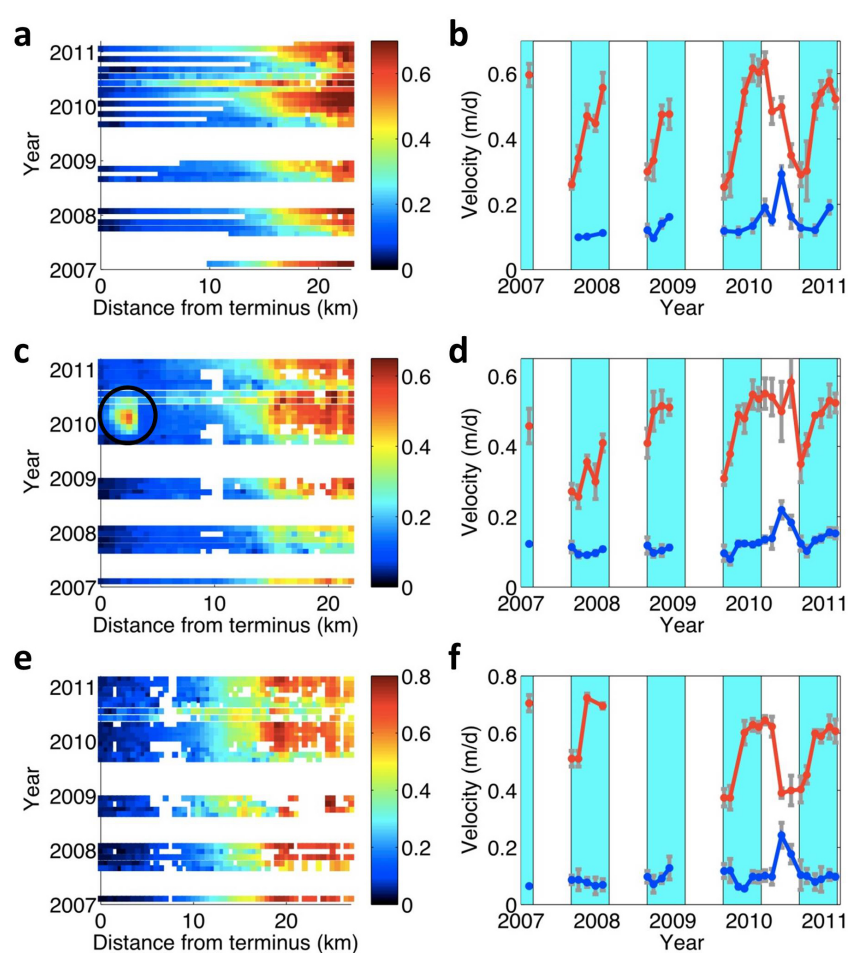

Figure 2. Left panels: Spatial and temporal changes in ice velocity along the flow lines of (a) Anderson, (c) Chitina, and (e) Walsh Glaciers. The profiles are plotted with $500 \mathrm{~m}$ intervals along the flow lines shown in Fig. 1. Black circle indicates the speed-up signal caused by Ottawa Glacier (a tributary of Chitina Glacier, and here is the confluence.). Right panels: Averaged time-series plots at two distinct sections derived from (a), (c), and (e), respectively. Red line shows upper region (b: 18-21 km of, d: $18-21 \mathrm{~km}$, f: $21-24 \mathrm{~km}$ ) and blue line do lower region (b: 5-8 km, d: 5-8 km, f: 4-7 km). Cyan shades stand for winter season (Sep-Feb).

mer (Fig. 2b, d, and f). For instance, over the $18-21 \mathrm{~km} \mathrm{sec-}$ tion on Anderson Glacier, the velocity was $\sim 0.5 \mathrm{~m} \mathrm{~d}^{-1}$ in early summer 2010 , but exceeded $0.7 \mathrm{~m} \mathrm{~d}^{-1}$ in the winter of 2009/2010 and 2010/2011 (Fig. 2b). Over the 18-21 km section on Chitina Glacier, the velocity was $\sim 0.5 \mathrm{~m} \mathrm{~d}^{-1}$ in the early summer of 2010 but also in the winter of 2009/2010 and 2010/2011 (Fig. 2d). Similarly, over the $21-24 \mathrm{~km} \mathrm{sec-}$ tion on Walsh Glacier, the velocity was $0.4 \mathrm{~m} \mathrm{~d}^{-1}$ in the early summer of 2010 but $0.6 \mathrm{~m} \mathrm{~d}^{-1}$ in winter (Fig. 2f). Moreover, in contrast to the propagation toward the upstream region of the summer speed-up observed in Greenland outlet glacier (Bartholomew et al., 2010), the higher-velocity area expands from upstream in autumn, to the downstream section in winter. This propagation toward downstream is most clearly observed at Anderson Glacier (Fig. 2a).

We could not obtain quality velocity data and much summer velocity data for each year due to large intensity changes associated with surface melting, and due to the data availability problem, except in the year 2010. Figure 2 shows summer speed-up signals in 2010 in the lower middle reaches at each 


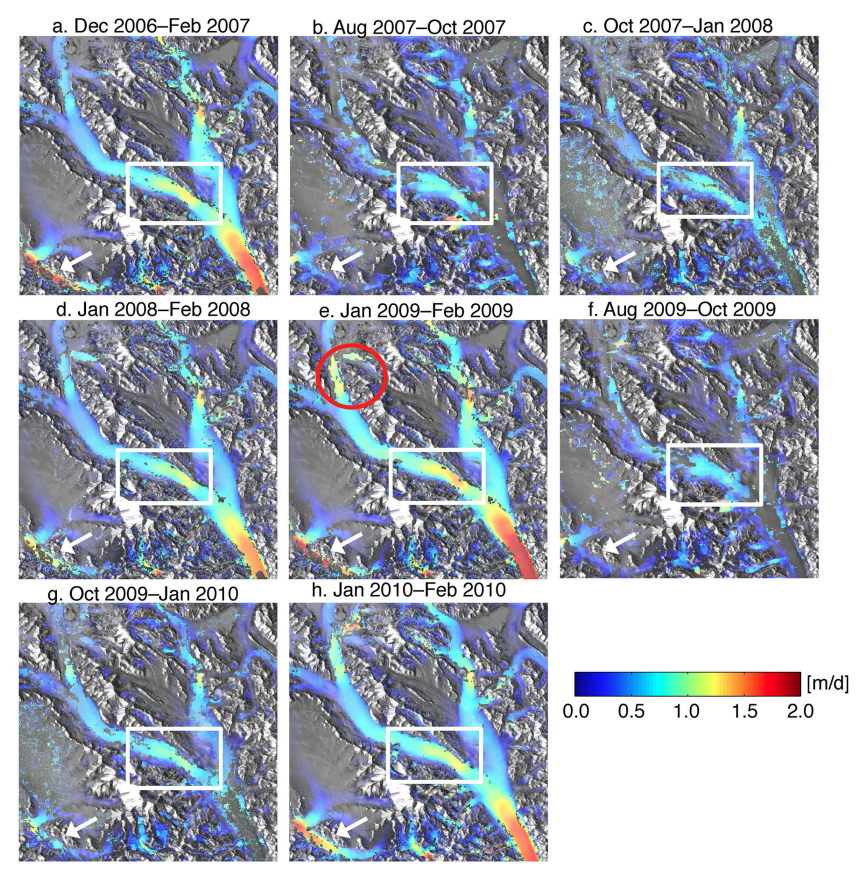

Figure 3. Spatial-temporal evolution of ice velocity at Hubbard Glacier and an upper tributary of Malaspina Glacier. The flow direction of Hubbard Glacier is from north to south. The white square marks a region in which the velocity in winter $(\mathbf{a}, \mathbf{d}, \mathbf{e}, \mathbf{h})$ exceeds that of late summer and autumn $(\mathbf{b}, \mathbf{c}, \mathbf{f}, \mathbf{g})$. The red circle in (e) marks a "mini-surge-like" signal in the upstream region during January-February 2009. The white arrow in this image shows a winter speed-up of an upper tributary of Malaspina Glacier.

glacier. In addition, compared to the gradual propagation of the winter speed-up toward downglacier, noted above, the summer speed-up in the lower reaches appears to occur primarily over a shorter period. The glacier dynamics at lower reaches thus seems to be consistent with previous findings.

For Hubbard Glacier, the only tidewater glacier in the study area, the $\sim 15 \mathrm{~km}$ length section in the midstream region has velocities in January and February that are $\sim 33-$ $60 \%$ greater than the velocities of the previous August to October (Fig. 3a, d, e, and h). The significant speed-up during the 2009 winter may be associated with a small surge in the upper tributary (Fig. 3e). The much smaller tributary in the upper reach of Malaspina Glacier (Fig. 1) also exhibits greater velocities in winter, suggesting that the winter speedup mechanism is independent of the glacier's size.

\section{Discussion}

According to the average air temperature at Yakutat Airport provided by The Alaska Climate Research Center data (http://akclimate.org), the monthly average temperature from 2006 to 2011 is about $0.2^{\circ}$ in November, and about $-2^{\circ}$ for December, January, and February. Almost all of our study area is above $1000 \mathrm{~m}$ a.s.l. Thus, the wintertime temperature is significantly below freezing, so there should be little surface meltwater during winter. Under such circumstances, it is likely that the mechanisms of winter speed-up and its downglacier propagation are different from those of the summer speed-up that usually propagates upglacier. Also, the detected annual winter speed-up in the upstream is up to $100 \%$ too high to be explained by snow accumulation, considering that the ice thickness in the area is a few hundred metres or more.

The observed winter speed-up in the upstream region may be regarded as a "mini-surge" (Humphrey and Raymond, 1994). However, not all previously reported mini-surges occurred in winter. For instance, the mini-surges prior to the 1982-1983 surge at Variegated Glacier occurred in summer (Kamb et al., 1985; Kamb and Engelhardt, 1987). A minisurge defined in Kamb and Engelhardt's paper indicates dramatically accelerated motion for a roughly 1-day period, which occurred repeatedly during June and July in 1978 1981. Although Kamb et al. (1985) noted an anomalous increase in wintertime velocities since 1978, the measurements were done only once in September and once in June (Raymond and Harrison, 1988), and thus they may include the spring speed-up signals as pointed out by Harrison and Post (2003). To the best of our knowledge, no comprehensive wintertime velocity observations have been done in upstream regions. However, even if sporadic speed-up events repeatedly occur from autumn to winter, we cannot distinguish them from gradual seasonal speed-up because of the present coarse temporal resolution. Nevertheless, it is important that our results clearly revealed flow velocity evolution from autumn to winter, indicating the increase is not monotonously towards the next summer.

We now compare our findings to previous studies. Iken and Truffer (1997) found a gradual speed-up from autumn to winter at the $\sim 2 \mathrm{~km}$ long downstream section of the temperate Findelengletcher in Switzerland, where the speed continues to increase, reaching a maximum in summer. In contrast, our observed winter speed-up occurs in the upstream region, and speed does not continue to increase after winter. Sundal et al. (2011) examined how ice speed-up and meltwater runoff are related at land-terminating glaciers in Greenland. The ice speed-up is affected by the amount of surface runoff each year, which differs between high and low melting years. The results indicate that the ice speed in a high melting year gradually increases from autumn to winter. However, the ice speed does not accelerate in low melting years. Moreover, they did not report the spatial distribution of speed during winter, and the maximum speed is apparently observed in early spring to summer. Our velocity data do not simply indicate the gradual speed-up from autumn to the next spring. The winter speed-up initiates upstream, and the maximum speed in winter is comparable to that in early summer. As some of the glaciers could not be examined with a high tem- 
poral resolution, it is likely that there are other winter speedup glaciers.

How can we explain the observed winter speed-up signals? First, we argue that the mechanism proposed by Kamb et al. (1985) for the Variegated Glacier does not apply here. In this mechanism, the efficient tunnel-shaped drainage system, which is present in summer, may provide a less efficient distributed system in early winter due to a depletion of surface meltwater and the destruction of conduits by creep closure. Thus, the subglacial water pressure may greatly increase. For our observed winter speed-up to be explained by this mechanism, there would have to be an efficient drainage system. Although such an efficient drainage system is often observed near the terminus (Raymond et al., 1995; Werder et al., 2013), the winter speed-up is observed upstream, far from the terminus. In addition, even if meltwater remnants exist in the upstream region, it is unclear how the subsequent speedup can be maintained without further input of meltwater from the surface. In the absence of meltwater input, subglacial cavities will be increasingly disconnected (Bartholomaus et al., 2011). Thus, we need to consider a mechanism that can trap water in the upstream in winter so that the subglacial water pressure can be maintained high enough to generate basal slip.

One such mechanism was proposed by Lingle and Fatland (2003). In that study, using the few ERS $1 / 2$ tandem radar interferometry data with the 1-3 days observation interval, they similarly detected a faster speed in winter than in autumn at the non-surging Seward Glacier in the St. Elias Mountains. They also found localized circular motion anomalies at both surging and non-surging glaciers that indicated local uplifting and/or subsidence caused by transient subglacial hydraulic phenomena. Combining their observations with earlier glacier hydrological studies, they proposed a model of englacial water storage and gravity-driven water flow toward the bed in winter that applies to both surge-type and non surge-type glaciers. Lingle and Fatland (2003) suggested that the size of englacial water storage would determine if a given glacier is surge-type or not.

Few winter speed-up observations have been made since Lingle and Fatland (2003), but our data suggests that winter speed-up may not be a rare phenomenon. Each local uplift and/or subsidence event in the Lingle and Fatland study must be a transient short-term process, episodically occurring in places. We could not observe such localized signals in our offset-tracking displacements because our observation interval, at least 46 days, is much longer than the 1-3 days in Lingle and Fatland (2003). Nevertheless, we propose that both Lingle and Fatland's and our observations are caused by the same physical processes. This is because the locally increased basal water pressure could increase basal sliding and contribute to larger horizontal displacements. Following Lingle and Fatland's hypothesis, our finding of winter speed-up signals at the quiescent surge-type glaciers seems to indicate the presence of sizable englacial water storage whose water volume will not only change seasonally but also evolve secularly until the next active surging phase. Considering that the observed glaciers are surge-type but during their quiescent phase, we speculate that total englacial water volume may not yet be large enough to generate the active surging phase.

Till deformation is another mechanism that causes glacier surge (e.g. Cuffey and Paterson, 2010), and some glaciers in Alaska and the Yukon have till layers. For example, Truffer et al. (2000) examined surface velocity and basal motion at the ice-till interface at Black Rapid Glacier in the Alaska Range, finding that the large-scale mobilization of subglacial sediments plays a dominant role in the surge mechanism. However, based on Coulomb-plastic rheology for till deformation (e.g. Clarke, 2005), substantial till deformation requires a high basal water pressure. So, regardless of the presence of a till layer, the mechanism for winter speed-up should include a process in which a high basal water pressure can be kept during wintertime.

Schoof et al. (2014) recently reported wintertime water pressure oscillations at a surge-type glacier in Yukon, and interpreted them as spontaneous oscillations driven by water input from englacial sources or ground-water flow. But without flow velocity data, they could not correlate the wintertime drainage phenomenon to glacial dynamics. The present observations though are consistent with the englacial water storage model of Lingle and Fatland, and thus may help explain our observed upstream glacier speed-ups in winter.

Although the englacial water storage model may explain the winter speed-up, the specific water storage system remains unknown (Fountain and Walder, 1998). One plausible form of englacial water storage is the basal crevasses observed by Harper et al. (2010) at Bench Glacier, Alaska. Such crevasses have no direct route to the surface, yet can store significant volumes of water near the bed. Thus, water in the basal crevasses may generate high pressure when they become constricted due to creep closure in winter.

The formation of basal crevasses in grounded glaciers requires a high basal water pressure that may approach the ice overburden pressure and/or requires longitudinally extending ice flow (van der Veen, 1998). Although such crevasses have not been detected in this area, their restrictive conditions might explain our observations of uncommon winter speedup signals and the distribution of surge-type glaciers in the area.

\section{Conclusions}

In this study, we applied offset tracking to ALOS/PALSAR data on glaciers near the border of Alaska and the Yukon to show their spatial and temporal velocity changes in 20062011. For many of the quiescent surge-type glaciers around the St. Elias Mountains, upstream accelerations occurred from autumn to winter and then propagated towards downstream. The winter speeds in the upstream regions were com- 
parable to, and sometimes faster than, those in spring to summer. Combining the absence of upstream surface meltwater input in winter with insights from some previous studies, we speculate that sizable water storage may be present near the bottom of glaciers, not directly connected to the surface, yet can enhance basal sliding by increased water pressure as they constrict in winter. Further observational and theoretical studies are necessary to decipher the winter speed-up mechanisms and determine if such water storage systems exist.

\section{The Supplement related to this article is available online at doi:10.5194/tc-9-1183-2015-supplement.}

Acknowledgements. The PALSAR level 1.0 data used in this study were provided by the PALSAR Interferometry Consortium to Study our Evolving Land surface (PIXEL) and the ALOS 3rd PI project, under cooperative research contracts between the Earthquake Research Institute, University of Tokyo, and JAXA. The PALSAR data belong to JAXA and the Ministry of Economy, Trade, and Industry (METI). ASTER GDEM is a product of METI and NASA. We acknowledge KAKENHI (24651001) for supporting this study. We also thank Shin Sugiyama and Takanobu Sawagaki for discussion. The comments from four anonymous referees and the handling editor were helpful for greatly improving this paper.

Edited by: E. Larour

\section{References}

Bartholomaus, T. C., Anderson, R. S., and Anderson, S. P.: Growth and collapse of the distributed subglacial hydrologic system of Kennicott Glacier, Alaska, USA, and its effects on basal motion, J. Glaciol., 57, 985-1002, 2011.

Bartholomew, I., Nienow, P., Mair, D., Hubbard, A., King, M. A., and Sole, A.: Seasonal evolution of subglacial drainage and acceleration in a Greenland outlet glacier, Nat. Geosci., 3, 408411, doi:10.1038/ngeo863, 2010.

Burgess, E. W., Forster, R. R., Larsen, C. F., and Braun, M.: Surge dynamics on Bering Glacier, Alaska, in 2008-2011, The Cryosphere, 6, 1251-1262, doi:10.5194/tc-6-1251-2012, 2012.

Burgess, E. W., Foster, R. R., and Larson C. F.: Flow velocities of Alaskan glaciers, Nat. Comms., 4, 2146, doi:10.1038/ncomms3146, 2013a.

Burgess, E. W., Larson C. F. and Foster, R. R.: Summer melt regulates winter glacier flow speeds throughout Alaska, Geophys. Res. Lett., 40, 6160-6164, doi:10.1002/2013GL058228, 2013b.

Clarke, G. K. C.: Subglacial processes, Ann. Rev. Earth Planet. Sci., 33, 247-276, 2005.

Clarke, G. K. C. and Holdsworth, G.: Glaciers of the St. Elias Mountains, in: Satellite Image Atlas of Glaciers of the World, edited by: Williams, Jr., R. S. and Ferrigno, J. G., USGS Professional Paper 1386-J, J301-J328, 2002.
Clarke, G. K. C., Collins, S. G., and Thompson, D. E.: Flow, thermal structure, and subglacial conditions of a surge-type glacier, Can. J. Earth Sci., 21, 232-240, 1984.

Cuffey, K. M. and Paterson, W. S. B.: The Physics of Glaciers 4th edition, Academic Press, 693 pp., 2010.

Flowers, G. E., Roux, N., Pimentel, S., and Schoof, C. G.: Present dynamics and future prognosis of a slowly surging glacier, The Cryosphere, 5, 299-313, doi:10.5194/tc-5-299-2011, 2011.

Fountain, A. G. and Walder, J. S.: Water flow through temperate glaciers, Rev. Geophys., 36, 299-328, 1998.

Frappé, T. -P. and Clarke, G. K. C.: Slow surge of Trapridge Glacier, Yukon Territory, Canada, J. Geophys. Res., 112, F03S32, doi:10.1029/2006JF000607, 2007.

Harper, J. T., Bradford, J. H., Humphrey, N. F., and Meierbachtol, T. W.: Vertical extension of the subglacial drainage system into basal crevasses, Nature, 467, 579-582, 2010.

Harrison, W. D. and Post, A. S.: How much do we really know about glacier surging?, Ann. Glaciol., 36, 1-6, 2003.

Hewitt, I. J.: Seasonal changes in ice sheet motion due to melt water lubrication, Earth Planet. Sci. Lett., 371-372, 16-25, doi:10.1016/j.eps1.2013.04.022, 2013.

Humphrey, N. F. and Raymond, C. F.: Hydrology, erosion and sediment production in a surging glacier: Variegated Glacier, Alaska, 1982-1983, J. Glaciol., 40, 539-552, 1994.

Iken, A. and Bindschadler, R. A.: Combined measurements of subglacial water pressure and surface velocity of the Findelengletscher, Switzerland: Conclusions about drainage system and sliding mechanism, J. Glaciol., 32, 101-119, 1986.

Iken, A. and Truffer, M.: The relationship between subglacial water pressure and velocity of Findelengletscher, Switzerland, during its advance and retreat, J. Glaciol., 43, 328-338, 1997.

Kamb, B. and Engelhardt, H.: Waves of accelerated motion in a glacier approaching surge: the mini-surges of Variegated Glacier, Alaska, U.S.A., J. Glaciol. 33, 27-46, 1987.

Kamb, B., Raymond, C. F., Harrison, W. D., Engelhardt, H., Echelmeyer, K. A., Humphrey, N., Brugman, M. M., and Pfeffer, T.: Glacier Surge Mechanism: 1982-1983 Surge of Variegated Glacier, Alaska, Science, 227, 469-479, 1985.

Kobayashi, T., Takada, Y., Furuya, M., and Murakami, M.: Locations and types of ruptures involved in the 2008 Sichuan earthquake inferred from SAR image matching, Geophys. Res. Lett. 36, L07302, doi:10.1029/2008GL036907, 2009.

Lingle, C. S. and Fatland, D. R.: Does englacial water storage drive temperate glacier surge?, Ann. Glaciol., 36, 14-20, 2003.

MacGregor, K. R., Riihimaki, C. A., and Anderson, R. S.: Spatial and temporal evolution of rapid basal sliding on Bench Glacier, Alaska, USA, J. Glaciol., 51, 49-63, 2005.

Meier, M. F. and Post, A.: What are glacier surges?, Can. J. Earth Sci., 6, 807-817, 1969.

Radić, V. and Hock, R.: Regionally differentiated contribution of mountain glaciers and ice caps to future sea-level rise, Nat. Geosci., 4, 91-94, 2011.

Raymond, C. F.: How do glaciers surge? A review, J. Geophys. Res., 92, 9121-9134, 1987.

Raymond, C. F. and Harrison, W. D.: Evolution of Variegated Glacier, Alaska, U.S.A., prior to its surge, J. Glaciol., 34, 154 169, 1988.

Raymond, C. F., Benedict, R. J., Harrison, W. D., Echelmeyer, K. A., and Strum, N.: Hydrological discharges and motion of Fels 
and Black Rapid Glaciers, Alaska, U.S.A.: implications for the structure of their drainage systems, J. Glaciol., 41, 290-304, 1995.

Röthlisberger, H.: Water pressure in intra- and subglacial channels, J. Glaciol., 11, 177-203, 1972.

Schoof, C.: Ice-sheet acceleration driven by melt supply variability, Nature, 468, 803-806, 2010.

Schoof, C., Rada, C. A., Wilson, N. J., Flowers, G. E., and Haseloff, M.: Oscillatory subglacial drainage in the absence of surface melt, The Cryosphere, 8, 959-976, doi:10.5194/tc-8-959-2014, 2014.

Sole, A., Nienow, P., Bartholomew, I., Mair, D., Cowton, T., Tedstone, A., and King, M. A.: Winter motion mediates dynamic response of the Greenland Ice Sheet to warmer summers, Geophys. Res. Lett., 40, 3940-3944, doi:10.1002/grl.50764, 2013.

Strozzi, T., Luckman, A., Murray, T., Wegmuller, U., and Werner C. L.: Glacier motion estimation using satellite-radar offset-tracking procedures, IEEE Trans. Geosci. Rem. Sens., 40, 2384-2391, 2002.

Sundal, A. V., Shepherd, A., Nienow, P., Hanna, E., Palmer, S., and Huybrechts, P.: Melt-induced speed-up of Greenland ice sheet offset by efficient subglacial drainage, Nature, 469, 521-524, 2011.
Truffer, M., Harrison, W. D., and Echelmeyer, K. A.: Glacier motion dominated by processes deep in underlying till, J. Glaciol., 46, 213-221, 2000.

van der Veen, C. J.: Fracture mechanics approach to penetration of bottom crevasses on glaciers, Cold Reg. Sci. Technol., 27, 213 223, 1998 .

Wegmüller, U. and Werner, C. L.: Gamma SAR processor and interferometry software, in Proc. of the 3rd ERS Symposium, European Space Agency Special Publication, ESA SP-414, Florence, Italy, 14-21 March, 1686-1692, 1997.

Werder, M. A., Hewitt, I. J., Schoof, C. G., and Flowers, G. E.: Modeling channelized and distributed subglacial drainage in two dimensions, J. Geophys. Res. Earth Surf., 118, 2140-2158, doi:10.1002/jgrf.20146, 2013.

Yasuda, T. and Furuya, M.: Short-term glacier velocity changes at West Kunlun Shan, Northwest Tibet, detected by Synthetic Aperture Radar data, Remote Sens. Environ., 128, 87-106, 2013. 